\title{
A REVIEW OF HUMIDIFICATION-DEHUMIDIFICATION DESALINATION SYSTEMS
}

Matheus Dias de Carvalho ${ }^{1}$, Jane Selia dos Reis Coimbra 1, Tiago Silva Miranda Lemos ${ }^{2}$, Jorge David Alguiar Bellido 3, Antônio Marcos de Oliveira Siqueira ${ }^{*}{ }^{*}$

${ }^{1}$ Department of Chemistry, Federal University of Viçosa, Brazil

2 The Alberto Luiz Coimbra Institute for Graduate Studies and Research in Engineering, Federal University of Rio de Janeiro, Brazil

3 Department of Chemistry, Federal University of São João del-Rei, Brazil

DOI: https://doi.org/10.29121/granthaalayah.v8.i5.2020.225

Article Type: Research Article

Article Citation: Matheus Dias de Carvalho, Jane Selia dos Reis Coimbra, Tiago Silva Miranda Lemos, Jorge David Alguiar Bellido, and Antônio Marcos de Oliveira Siqueira. (2020). A REVIEW OF HUMIDIFICATIONDEHUMIDIFICATION DESALINATION SYSTEMS I. International Journal of Research GRANTHAALAYAH, 8(5), 290-3s11. https://doi.org/10.29121/granthaa layah.v8.i5.2020.225

Received Date: 18 May 2020

Accepted Date: 31 May 2020

Keywords:

Desalination

Humidification-Dehumidification

Solar Collector

Thermal Process

Water

\section{ABSTRACT}

This article aims to accomplish a review of state of the art in the humidification-dehumidification (HDH) desalination process. Foremost, an introduction to the main desalination technologies is presented to clarify the positives and negatives effects of each. Costs and project data are presented for experimental and theoretical studies. The information is shown by using tables, explaining the major variables, and the obtained results for each study. News regarding plants under the sea and packed beds are the main considerations of the present paper.

\section{INTRODUCTION}

The potable water is a primary substance for the existence of all kinds of known life; therefore, it lacks is highly worrisome for the human species. Statistics present that about 700 million of people does not have access to potable water on the world, [1] in addition to that, half of the world population suffers from severe water shortage at least one month per year. [2] Therefore, the consequent use of impure water is one of the biggest causes of diseases and deaths in our planet. [3] 
Matheus Dias de Carvalho, Jane Selia dos Reis Coimbra, Tiago Silva Miranda Lemos, Jorge David Alguiar Bellido, and Antônio Marcos de Oliveira Siqueira

With the increase of the population and the industrialization, the need for this recourse has enlarged with the years. Provisions show that in 2025, 1.8 billion people will suffer from water shortage; besides, approximately twothirds of the world population will have some difficulty to access it. [4] In 2030, the demand will be 6,900 billion cubic meters of potable water, although the estimated quantity available will be 4,500 billion, approximately. [5] The seawater represents $97 \%$ of our planet water, covering approximately $70 \%$ of the terrestrial surface. [6] Due to this fact, methodologies aiming for the transformation of saline water to potable water has been studies, to supply the scarcity of the last one. The accomplishment of seawater desalination is considered the best solution, and its favor would argue that about $40 \%$ of the world population lives in situated regions of distances up to $100 \mathrm{~km}$ from the coast. [7] Studies exhibit that 1\% of the world population depends on desalination water having a production of 74 million per cubic meters per day, approximately. [6]

Among the developed procedures for the seawater purification, there are two main strands: based on the evaporation or with the use of semipermeable membranes. [8] Both approaches need a power source to accomplish the purification; therefore, the main purpose is the maximization of potable water production for a specified amount of energy expended in the process. The processes with membranes are used in distant regions of the equator line, majoritarian, due to the low solar radiation incidence. At equatorial localities as the Middle East and the Brazilian Northeast, the thermal processes are more attractive due to the use of solar energy from collectors. [6]

The dependent processes of thermal sources have the heat as energy for the warming of the evolved fluids. In contrast, the processes evolving membranes, the energy source aimed is electrical, being responsible for feeding the high-pressure pumps or for creating electric fields to displace the ions. [8] The firsts energy sources to be explored were the ones from fossil fuels; however, these are inexhaustible sources, harmful to the environment, and have variable cost. The most used sustainable alternative is solar energy that is usually abundant in regions that suffer from water scarcity. [9]

The desalination processes do not emit gases that intensify global warming. However, one of the biggest environmental problems is water disposal with great salt concentrations. There are three alternatives to work around the problem: to transport the saline water to a body of saline water, to evaporate the water by solar radiation exposition, or to inject the brine in underground regions of high salinity. [6] Feed systems by a thermal source cannot dispose of water at high temperatures, dealing with another environmental problem. Among the damages caused, it is noticed the decrease in oxygen quantities that might be dissolved per liter of water. This fact begets fishes and other aquatics being's death dependents of oxygen to make up its vital functions. The great solution for the last case is the energy use of the output currents through heat exchangers to warm the input currents. Another solution is the recirculation of currents in the system if it is a viable procedure.

The pioneer desalination method from a renewable source is the o Solar Still (ST), initially developed by Corrols Wilson. [10] These desalination plants are resumed to a chamber with a coated bottom with dark paint to retain a larger quantity of radiation. This medium is covered by a slanted and sealed glass cover aiming to collect the potable water and to reduce possible leaks. At the bottom of the chamber, there is saline water that is heated by the absorption of solar radiation. Thus, the mass transfer of water from the air to the chamber is verified. At the moment that the saturated air by the vapor reaches contact with the cold surface of the glass cover, there is the condensation of molecules. The condense move by gravity until the inferior part of the chamber, when it is collected. [11]

The direct desalination system aforementioned stands out by its simplicity. However, it has been shown inefficiency energetically, being applied only for familiar's demands. The energy efficiency of these desalination plants under optimal conditions is about 30 to $45 \%$, with daily production inferiors of 5 L per each square meter of water surface per day. [12] The humidification-dehumidification (HDH) system that will be approached by this text accomplishes the separation between the mediums where the evaporation and condensation occur, using the latent heat that was before lost by the glass at the bottom of the direct desalination system. Therefore, it produces a quantity of potable water five times bigger with the same quantity of heat supplied. [13]

This study aims to accomplish a review of state of the art for the HDH desalination technology to clarify the main progress that occurred in the area. Furthermore, it will be exposed to environmental conditions at which the experiments were submitted, enabling the comparative study. 


\section{DESALINATION TECHNOLOGIES}

Methodologies to search for high efficiency of solar still systems were proposed with time; however, none of them were sufficient for a definitive adoption. Many times, these measures provided enormous complications in the desalination process characteristics, for example, the reduced pressure operation [14] that faced great difficulties of execution. It also occurs an attempted to create multiplex effects, therefore, searching to achieve the latent heat utilization of the vapor produced. Nevertheless, a decrease of incident radiation over the water was verified in the chamber interior and accumulation of salts in the glass. The Hassan et al. study mentioned a reach up to $57 \%$ of efficiency for the double effect system, [15] posteriorly Yeh and Chen presented a system with $13 \mathrm{~L} \cdot \mathrm{m}^{-2} \cdot \mathrm{day}^{-1}$ of production. [16] However, productivity does not overcome the HDH systems most efficiently. Figure 1 presents the subdivision among the main desalination methodologies.

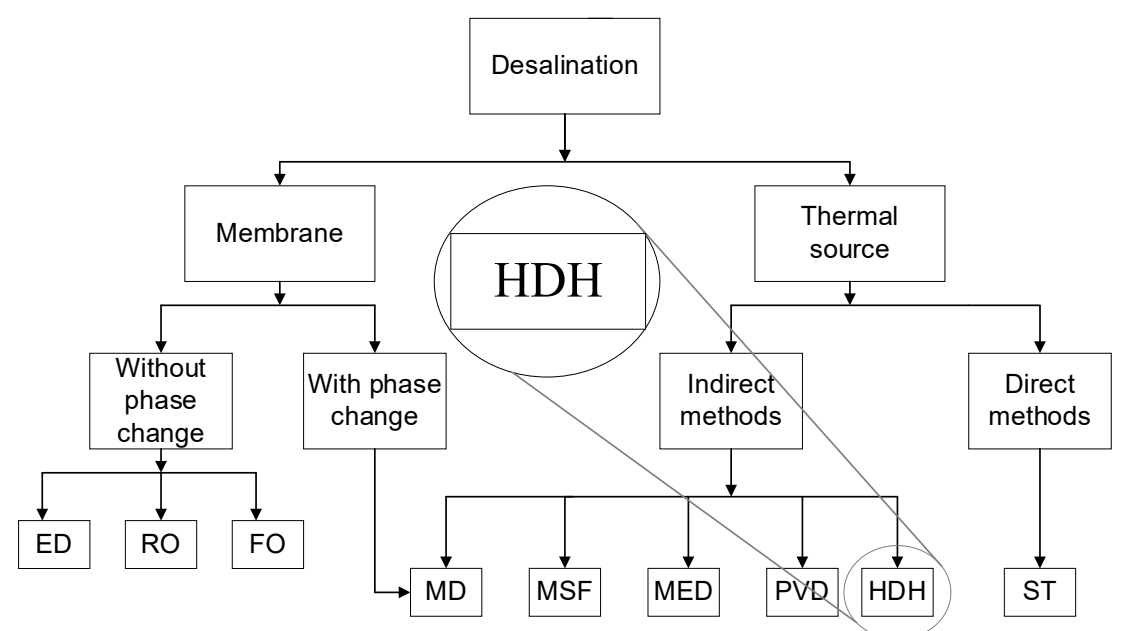

Figure 1: Classification of the main methods existing for desalination.

The most important commercial desalination processes based on thermal energy are the multi-stage flash (MSF) and the multiple effect distillation (MED). [3] These two desalination methodologies consist of several stages in series, in which there are pressure and temperature decrease as the effects advance, besides a successive increase of salinity. The water vapor created in these systems is posteriorly compressed, aiming to obtain the potable water, the compression can be achieved by a thermal (TVC) or mechanical (MVC) source.

The desalination method MSF is based on the vapor generation by the interval depressurization of seawater that goes into an evacuated chamber being depressurized on each stage. This process is based on the use of the existing energy in the vapor phase for heating of feeding current. Before the saline water accesses the depressurized stages, this current goes to a heat exchanger which is heated by contact with a vapor current at $100^{\circ} \mathrm{C}$.

In the MED methodology, it occurs the heating of the saline water for each effect. This heating occurs with the vapor created at the posterior effect, being a more effective system than the MSF. [17] The higher the stage numbers, the bigger will be the process efficiency; however, to find an optimal number of stages, it must be accomplished a cost analysis. [18]

Vacuum pumps are dispositive that spend a large energy expenditure, being accounted for as a problem in the operational costs analysis of the MED and MSF systems. Aiming to develop a desalination system which it would not have the necessity of this dispositive, it was created the Passive Vacuum Desalination (PVD) process. In this process, there is a waterfall of at least 10 meters that beget vacuum in the evaporator. Consequently, it occurs the saline water boiling temperature decrease. [18]

Desalination methodologies by membranes were created to reply to the biological process of purification that occurs in the kidneys. Among those systems, the electrodialysis (ED), forward osmosis (FO), reverse osmosis (RO), and membrane distillation (MD) stand out. The first three ones exhibited are more interesting to accomplish the desalination due to the lack of phase change to occur the separation, not needing to provide latent heat for the water vaporization. However, these processes need constant maintenance due to the successive depositions of the particulate, increasing the operation cost. Also, there is an imminent need for electrical power to supply the highpressure pumps, scarce provision in remote locations. 
The electrodialysis (ED) is a procedure that requires electricity to migrate the ion through a series of cationic and anionic membranes. The saline solution is pumped between membranes of opposite charges, which created an electric potential leading to the displacement of the ions. [19] The forward osmosis (FO) is a procedure that occurs previously, the initial solution dilution and posteriorly, the desalinated water extraction through the membrane. This process needs difficulties and onerous after treatments, and generally, it is not a viable process. [20] The reverse osmosis (RO) is among the most efficient desalination methods on a large scale; however, there is the need for a pretreatment of the seawater. [21] This procedure uses high-pressure pumps to create a reverse flux of mass transference. In contrast, those dispositive have greater valor, not being interesting for the small scale or in highly contaminated mediums use. The amount of required pressure is directly proportional to the saline concentration. The membrane distillation (MD) is a method that uses the membranes as the thermal energy to desalinate the water. In this case, the saline solution is heated until its vaporization, and this vapor goes for a hydrophobic membrane that only permits the water passage in the gas state, with the help of a compressor. [21] A condenser on the opposite side of the membrane is used to transform the vapor in potable water. Ordinarily, it is necessary high pressure for the gas to exceed the membrane, which makes the procedure impracticable.

The desalination plants by reverse osmosis control the world market, comprehending $65 \%$ of the operational capacity installed in the world. [22] The reverse osmosis has been presenting a constant increase in the installation number; however, it does not reach the Gulf Cooperation Council (GCC) and Middle East-North Africa (MENA). In the mentioned regions, there is a domain of MSF and MED plants due to the existence of high salinity, which difficult the pre-treatment stages needed for the process that involve membranes. MSF processes represent more than $90 \%$ of the thermal desalination plant installations, while the RO includes more than $80 \%$ of the processes, including membranes. [8]

Small size desalination plants that produce less than $100 \mathrm{~m}^{3}$ per day of potable water are generally the costliest when compared to the cost of produced $\mathrm{m}^{3}$. For a small scale, the RO has been highlighted as the most economical system obtaining 3 dollars cost per cubic meter of potable water. [23] However, plants of this class need high qualification labor for operation and manufacture, becoming a challenge in needy locals.

\section{HUMIFICATION-DEHUMIDIFICATION DESALINATION (HDH)}

Wilson was the first to develop an HDH desalination plant based on solar energy as a heat source, and this was created to supply a mining district. [24] Posteriorly, other plants were also built in Jordan [25] e Malaysia. [26],[27] The HDH desalination system is an attempt to reply to a natural phenomenon that occurs in coastal regions. At those locals, the solar radiation induces humidification of the air through the evaporation of the seawater. This humid air moves to higher altitudes, forming clouds that posteriorly precipitate. ${ }^{[8]}$ Therefore, the transformation of seawater in potable water occurs as it can be seen in Figure 2.

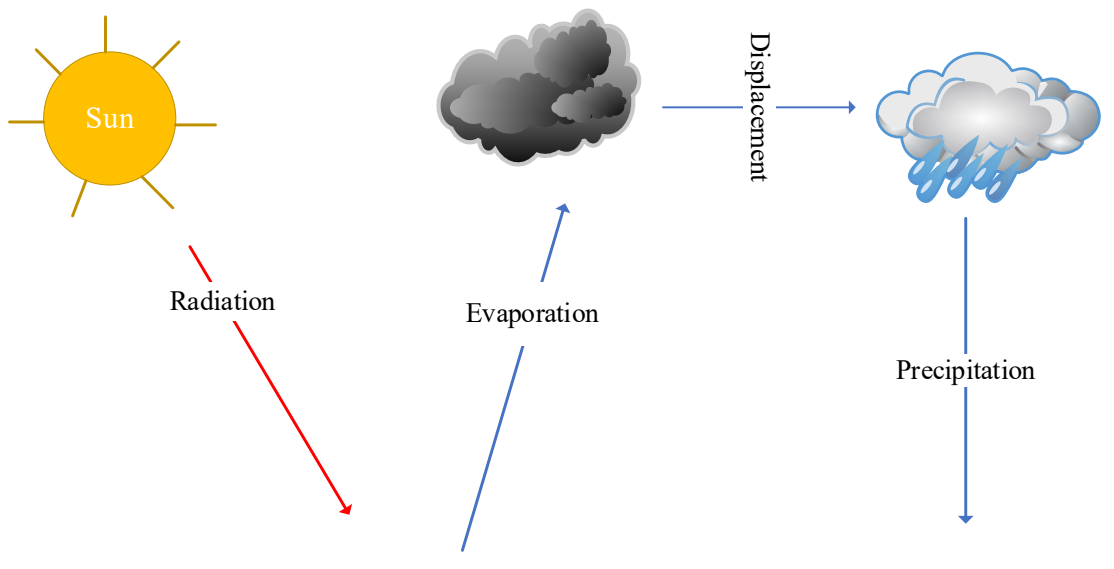

Figure 2: Schematic representation of the rain cycle in coastal regions. 
The HDH is an alternative to the usual desalination techniques, and it stands out for doe not need a hightemperature source or a vacuum pump to cause the evaporation. This methodology uses atmospheric air to transport the water vapor of a humidifier to a dehumidifier; consequently, the operation might occur at atmospheric pressure and low temperature. The heat to increase mass transfer is supplied to the flow of air, water, or both. After heating, the fluxes interact in the humidifier, which increases the humid air. After that, the energy is removed from the humid air by a refrigerant fluid in the dehumidifier, producing potable water.

As attractive as its advantages are, the HDH desalination systems require improvement at some factors as the provided latent heat recuperation, the optimization of mass and heat transference processes, besides to reduce the heat loss of all the system. Besides, it is cited the necessity to attain energy self-sufficiency, operating 24 hours for the day, which is only possible until now with the use of thermal storage tanks.

An HDH desalination system generally is composed of the following equipment: solar collector, compressor, condenser, humidifier, economizer, potable water tank collector, and control system. The components efficiencies are interrelated as the output current is the input current of another. The economizer is a heat exchanger that performs the recuperation of saline water energy that leaves the process. Figure 3 presents a schematic flow chart of a typical HDH desalination system.

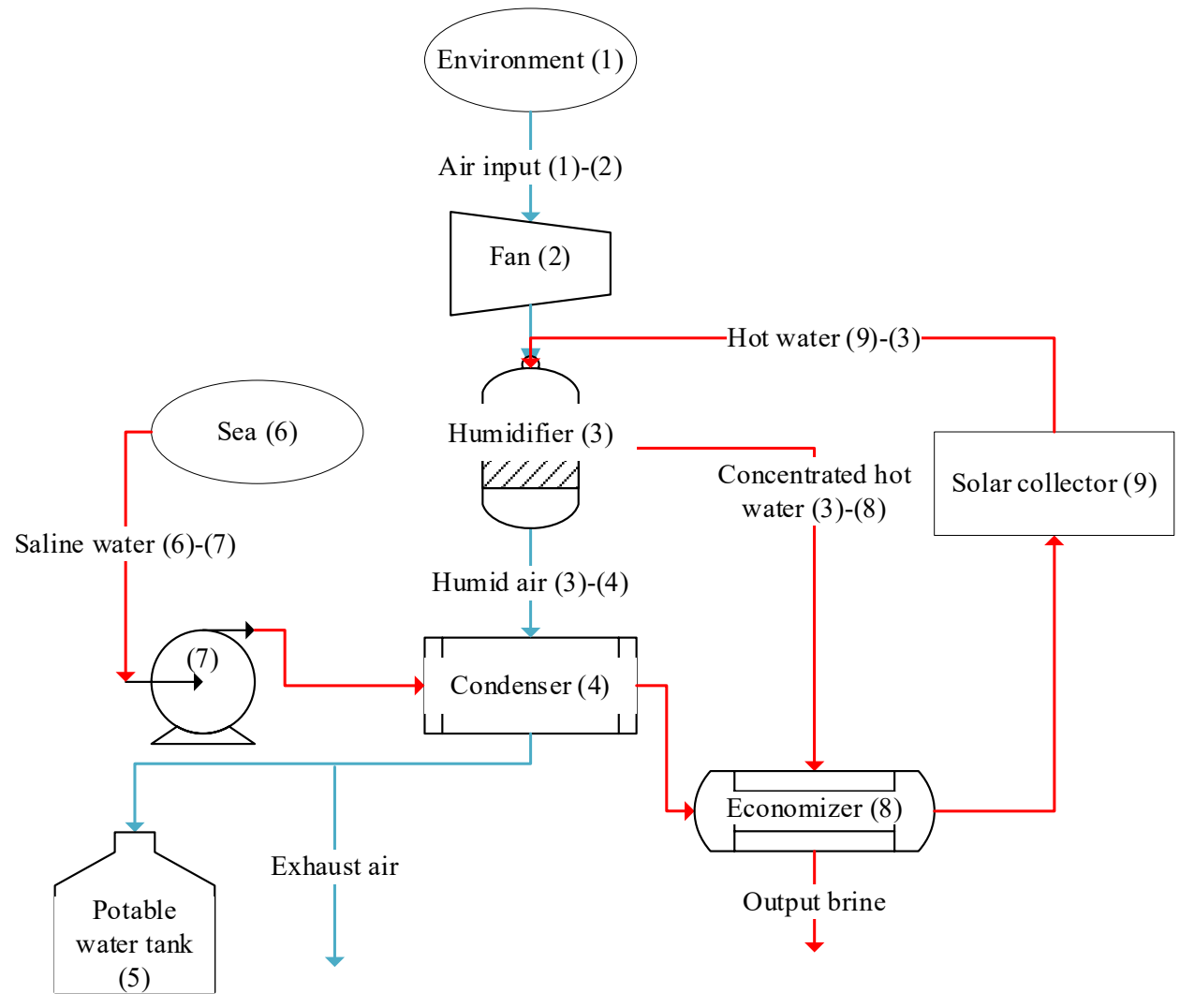

Figure 3: Typical compounds of an HDH desalination system with heating only in the water current.

The solar collectors correspond to $40 \%$ of the installation cost of an HDH unity, approximately. [28] The existent variations in the market and that might be used in the desalination process are diverse, among them, it is cited the solar ponds, heliostat field collector, evacuated tube collectors, flat plate collectors, parabolic dish reflector, cylindrical trough collector, compound parabolic collector, linear Fresnel reflector and the parabolic trough collector. All those collectors are studied by Chaibi and El-Nashar, [29] enabling the best choice for each project. Based on the literature, it is noted that the flat plate collectors are one of the most used in desalination systems. [30] Figure 4 presents the most diverse classification forms for an HDH desalination system. 


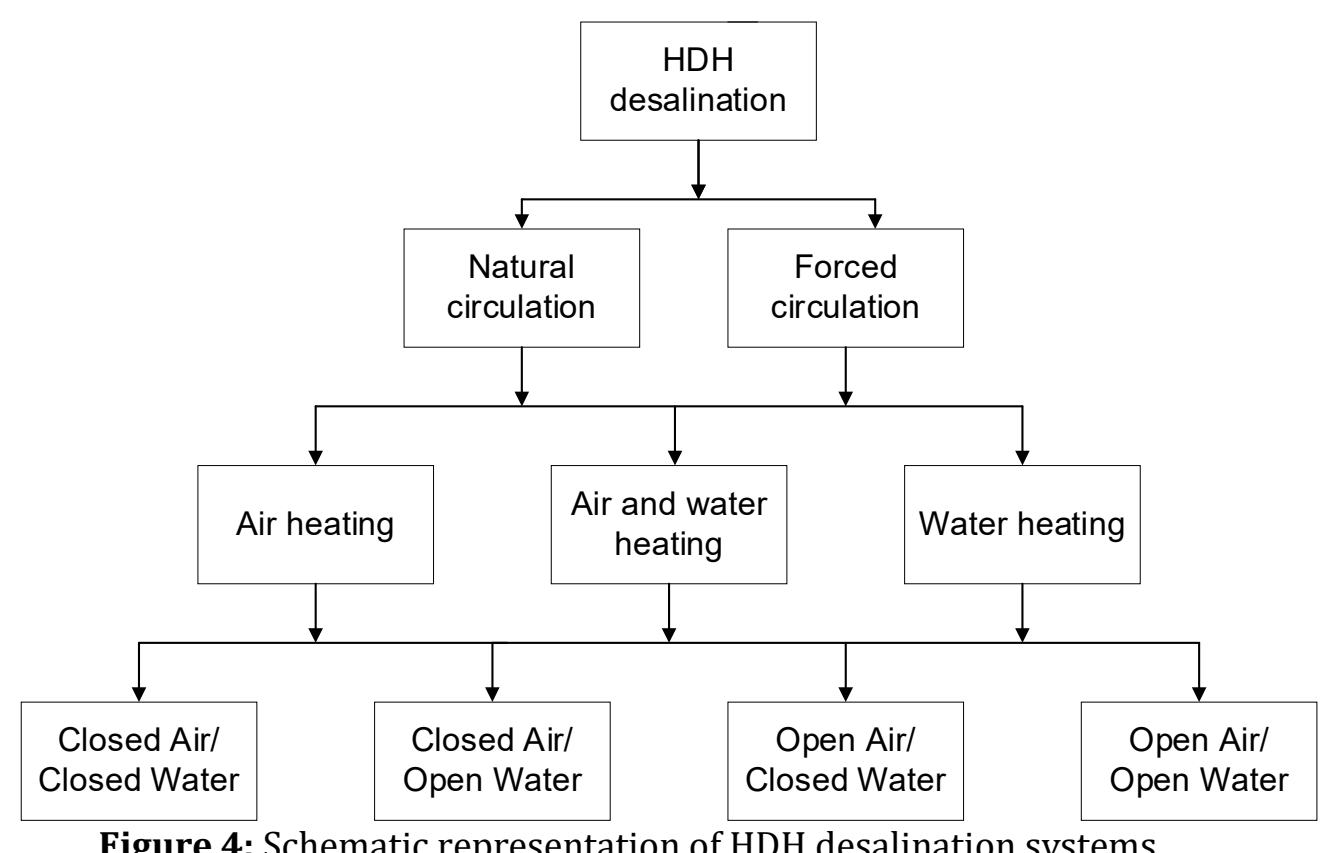

Figure 4: Schematic representation of HDH desalination systems.

The first ramification presented in Figure 4 refers to the air circulation form that might be natural or forced, but, in general, the HDH installations are the forced type in order of the better air flux targeting in the cycle interior. Also, there is a classification as the humidifier input currents heating, which might warm the air or the water or both fluids solely.

The restrict heating of the air current is not usual in the literature as it is noted by Bretano work findings, which it is analyzed the performance of the humidification stage in an HDH system. [31] The restrict heating of the air implies more significant expenses in the condensation stage due to the need for a greater surface area than the one on the humidification stage. [32] This fact is due to an imminent necessity to lead the overheated air until its dew point. The main variable to attain a high efficiency is the input temperature of the saline water flux, due to the air temperature that leaves the humidifier tends to be equal to the input water temperature. [31] Also, the air capacity to transport humid increases exponentially with the temperature. [30] Consequently, a high seawater temperature leads to a bigger water transportation tax to the condenser.

The process fluids recirculation viability depends on the environmental conditions; for each climate, there is a better configuration associated. In closed air/closed water systems, there is recirculation in the water and the air, and this configuration presents higher global efficiency than the others, this fact is due to the latent heat condensation recovery. This system is attractive to locals with low air humidity, besides low seawater and air temperature. However, the salt concentration in the seawater increases in each cycle. This phenomenon intensifies the sedimentation risks, fouling, and difficulty to accomplish the mass transference.

The closed air/open water system must be used in locals with low ambient air temperature and humidity, besides the energy contained at the saline water that leaves the system must be sufficiently low. In open water systems, it is usually used its input saline water as a cooling fluid in the condenser. The open-air/closed water process must be applied with exhaust air with temperature and humidity inferior to the ambient air, besides the saline water temperature after each cycle must be superior to the possible external source. In closed water systems, it is necessary a cooling fluid for the condenser due to the high-water recirculation temperature.

Eventually, the humidification region might contain a packing column, and this has the purpose of increasing the mass transference between the air and water currents. Therefore, there is a heat loss rise, occasionally creating the salts carriage by the gas current and fouling in the packing. That addition of heat loss begets a necessity for pumps and compressors higher performance that boosts both fluids; consequently, there is higher energy expenditure. The packing fouling tends to increase the heat loss, which decreases the process efficiency and entails the need for periodic stops for the packing cleaning, task that reduce the system productivity. Problems related to corrosion are notorious in these situations, mainly due to the high salts' concentration attained by the fluid currents. It is noticed 
the need for specific pipes for desalination plants due to the saline water is highly corrosive, effect increased by biggest temperatures. [26]

The open-air/open water systems are not common due to the large heat loss in the output currents, besides its vulnerability with the environment conditions variations. Therefore, it might be interesting when the ambient air has temperature and humidity superior to the air that leaves the condenser; besides, the water temperature that enters the process must be greater than the one that leaves the humidifier. Related problems to salts concentration in the system are discarded. Furthermore, it is possible to couple a heating exchanger to recover energy, which increases the energetic efficiency of the system. The Table 1 presents a resume of the main characteristics of each an introduced configuration.

Table 1: Relevant characteristics of the main configurations for the HDH desalination systems.

\begin{tabular}{|l|c|c|c|c|}
\hline Characteristic & $\begin{array}{c}\text { Closed air/ } \\
\text { Closed water }\end{array}$ & $\begin{array}{c}\text { Closed air/ Open } \\
\text { water }\end{array}$ & $\begin{array}{c}\text { Open-air/ Closed } \\
\text { water }\end{array}$ & $\begin{array}{c}\text { Open-air/ Open } \\
\text { water }\end{array}$ \\
\hline Ambient air temperature & Low & Low & Moderate/High & Moderate /High \\
\hline Seawater temperature & Low & Moderate /High & Low & Moderate /High \\
\hline Energy use & High & Low /Moderate & High & Low \\
\hline Fouling/ Deposition & High & Low & High & Low \\
\hline Addition cooling current & Yes & No & Yes & No \\
\hline
\end{tabular}

The HDH desalination system is promising since its cost, and energetic efficiency are low on a rural scale. Differently of the membrane methodology, this favors the brine purification being a strong candidate for the natural gas wells desalination. There are other advantages, such as simplicity, moderate installations cost, low operation cost, and flexibility. HDH systems allow the coupling in a simple form to accomplish the fluids warming, not needing higher costs with that plant sector, differently of other methodologies that need a higher quantity of energy. As the devices for solar power collect usually are costly for a desalination plant, this is a great appeal of the HDH methodology.

\section{DISCUSSIONS}

This section presents some of the critical studies of the HDH desalination system in chronological order, aiming to highlight the area improvements.

Nawayseh et al. [25] study through computational simulations the performance of an HDH desalination system built-in Jordan by 1993. It was found optimums conditions for unity performance through various parameters evolved in the system. The simulated data presented a good correlation with the experimental one, having determined discrepancy as a function of the heat and mass transference coefficient used, not being of the same plant. During the simulations, it was obtained great mass flows for the water and the air beside a condenser surface area of $4 \mathrm{~m}^{2}$.

Al-Hallaj et al. [12] studied a desalination cycle with air recirculation and water elimination, in which there is the current seawater heating through a plane solar collector. In this experimental study was built two HDH unities to evaluate the air velocity, the condenser area, the humidifier area, temperature, and water flux rate influence. Specific a particular solar collector area available, additions of the water flux are essential due to the increase of available liquid in the mass transference. Therefore, there is a marked decrease that causes a reduction in the evaporation and condensation efficiency; that balance leads to the definition of optimum flux. The air velocity has presented as a significant parameter only at low temperatures; consequently, it does not become interesting to invest in a powerful compressor for the hot air recirculation. Figure 5 presents a schema of the desalination cycle studied.

Nawayseh et al. [26] accomplished an experimental study to find correlations for the mass and heat transference coefficients evolved in the humidification stage of the air currents. These coefficients are useful to model the system computationally, enabling to find optimums parameters for several conditions. These parameters are representative of a closed air system with natural convection circulation. It is analyzed three HDH plants, being these built-in Jordan and Malaysia. 


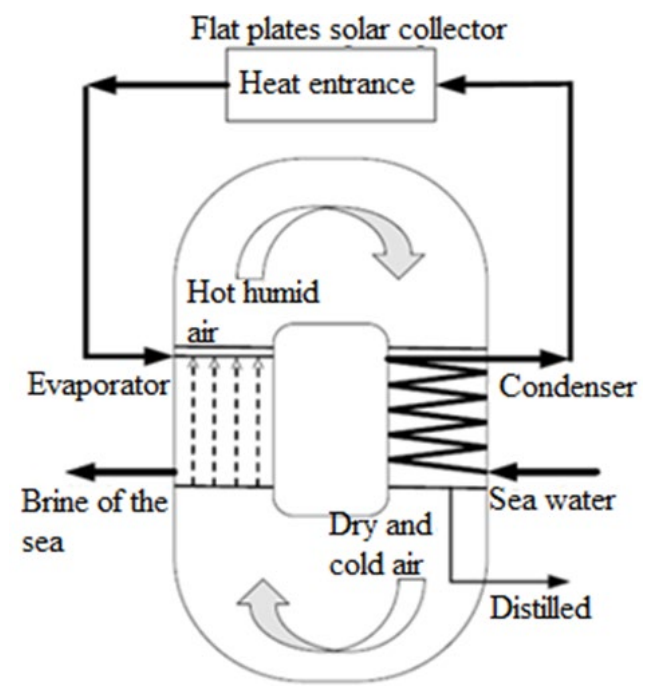

Figure 5: Representative schema of a desalination plant with air recirculation and saline water disposable. Adapted from ref. [12].

Dai and Zhang [10] performed an experimental study for the HDH open-air/closed water HDH desalination system, which it is noted a strong dependency of the system performance when compared to the input seawater temperature at the humidifier. This study also defines the existence of an optimum rotation for the compressor, corresponding to good mass flux for the air to develop high thermal efficiency and water production. The thermal efficiency produced by the plant was measured at $85 \%$ under optimal conditions, presenting to be highly productive at arid locals. To achieve high efficiencies is was used as a layer in the humidifier, aiming to increase the mass and heat transference among the currents. Figure 6 presents the dispositive built in this study.

Dai et al. [24] developed a mathematical model to represent one of its previous [10] paper, validating as an experimental model already built. Besides, it was performed a parametric analysis, optimizing the unity performance. The daily productivity of the system for each solar collector square meter was $0.25 \mathrm{~kg} \cdot \mathrm{h}^{-1}$, with the daily energy supply of $20 \mathrm{MJ}$, data based on the climate conditions of the Xian city, China. The water recycles in the system when it has low salt concentration and high temperature. The parametric analysis presented the existence of an optimum air flux, for which the potable water production was maximized. Furthermore, it was noticed that the produced water quantity increased with the rise of the air temperature, the relative humidity, the seawater, and the cooling water fluxes.

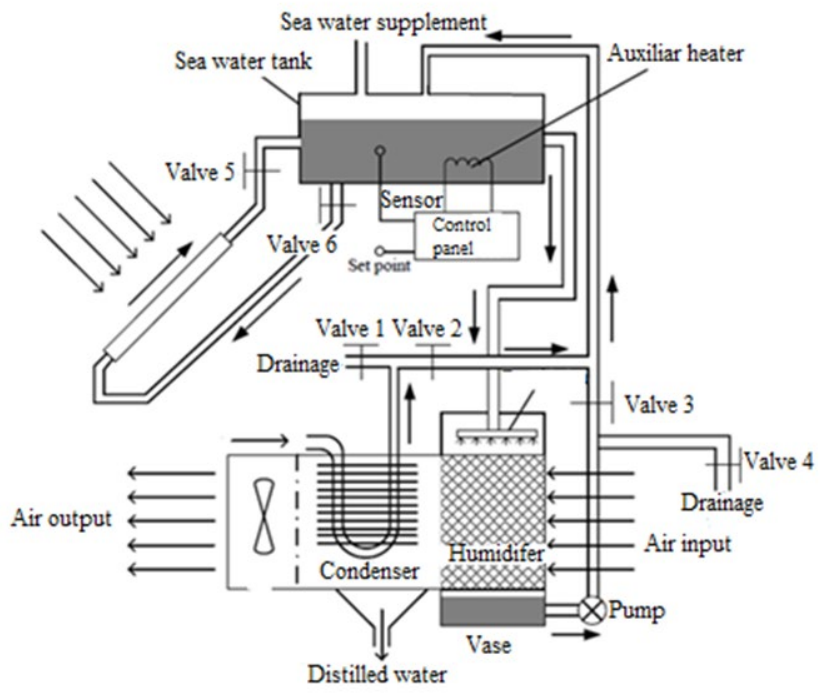

Figure 6: Representative schema of an open-air/closed water desalination plant with forced circulation. Adapted from ref. [10]. 
Yuan and Zhang [33] accomplished a study aiming to associate the solar collector area, the cooling water flux, the seawater flux, and the equipment dimensions with the collected potable water quantity. Those data are referent to an HDH system of closed air/closed water built in the Xian region, China. It was noted a decrease in the production with an increase of the saline water flux and with the change of season, falling for half in the winter. Besides, it was noticeable the raise of production with the following increases at the cooling water flux.

Amer et al. [34] accomplished a theoretical and experimental study of the productivity conditions in a closed air/open water desalination system with layer coupling. The heat and mass transference coefficients were measured at different conditions for the three layers types. Empirical correlations express their curves. The results showed that the productivity increased proportionally to the water mass flux at the studied range, as well as the condenser input and output air humidity. The proportionality between the condenser output water temperature and the humidifier input water temperature was another verified result. The latter diminished with the increase of the mass flux. The rise of the input or output air temperature in the condenser presented direct relation with the major humidifier input water temperatures. Regarding the air circulation, the forced form did not present greater improvements for the fluid at high temperatures. The maximum productivity achieved was $5.8 \mathrm{~kg} \cdot \mathrm{h}^{-1}$, obtained with a wood layer operating under forced convection for the humidifier input water of $85^{\circ} \mathrm{C}$ and seawater flux of 168 $\mathrm{kg} \cdot \mathrm{h}^{-1}$. Figure 7 represents the studied plant in this paper.

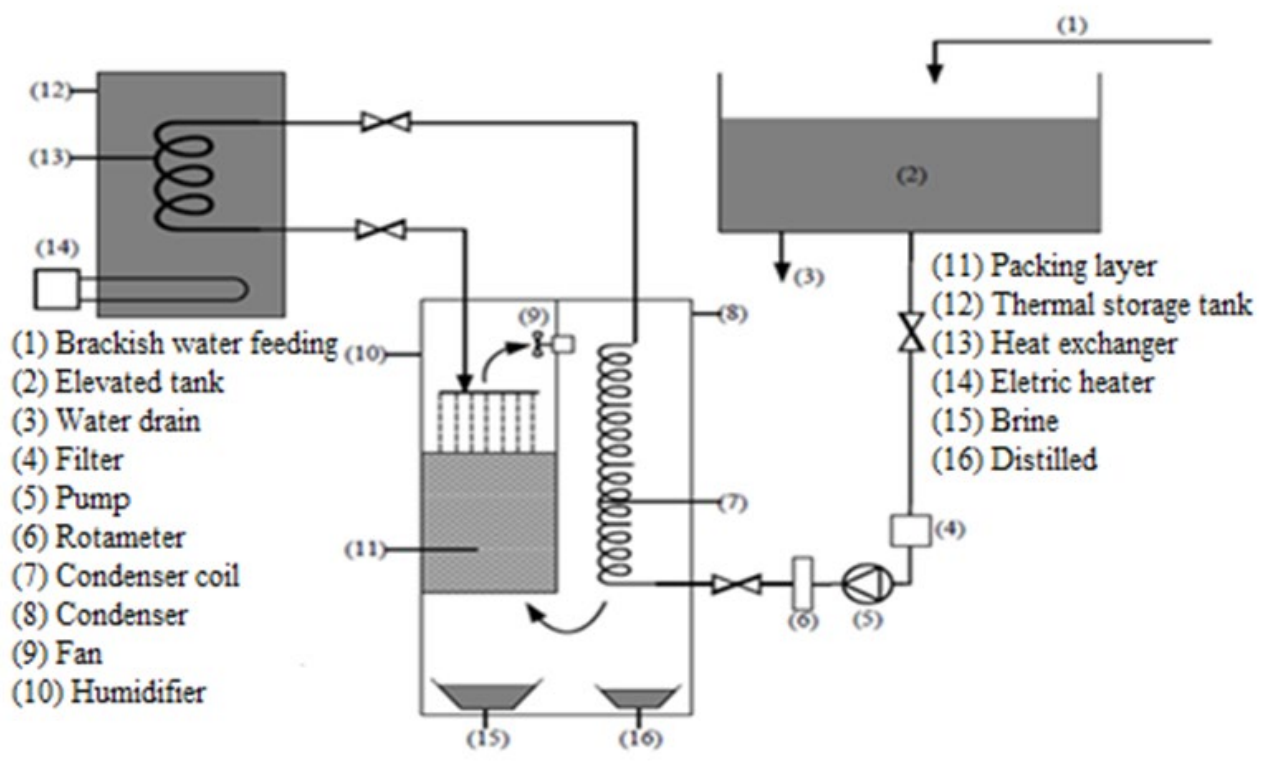

Figure 7: Representative schema of a desalination plant. Adapted from ref. [34].

Narayan et al. [8] accomplished and state of the art literature review of HDH desalination systems. They defined and evaluated the main parameters to compare the performance among the cycle variations developed until now. Furthermore, they created new proposes to improve the analyzed cycles. The paper is concluded appearing the HDH technology relevant at small scale desalination besides noticing the necessity to improve efficiency and reduce capital costs.

Mahmoud et al. [35] performed a theoretical and experimental study aiming to compare the closed air/closed water and open-air/closed water system in a single stage. The device was installed in Minya Governorate city, Egypt, which had its averages climate conditions used in the simulations, region with air humidity between 30 and $40 \%$. A thermal storage tank of glass wool coated steel was used, aiming to minimize the heat loss. Moreover, an electric heater was needed to adjust the saline water temperature that supplies the humidifier. The humidification and dehumidification chambers consist of cubic structures of galvanized steel, covered by a polymeric layer. In this study, it was obtained saline water temperatures sufficiently high for both cases, enabling the water recycling. Also, the authors concluded that the closed cycle for the air was more productive.

Zamen et al. [36] studied the experimental closed air/closed water HDH system with two stages. This article presented results for cold and hot days of an arid local, aiming to optimize the freshwater production for a small solar collector area. The system proposed has exhibited $20 \%$ more efficient than a similar one with one stage, 
presenting to be better as the cost and efficiency. The authors also calculated the efficiency of the system for more two stages, noticing not significant improvements, concluding that the two-stage operation would be the best option. Figure 8 represents the built plant disposition.

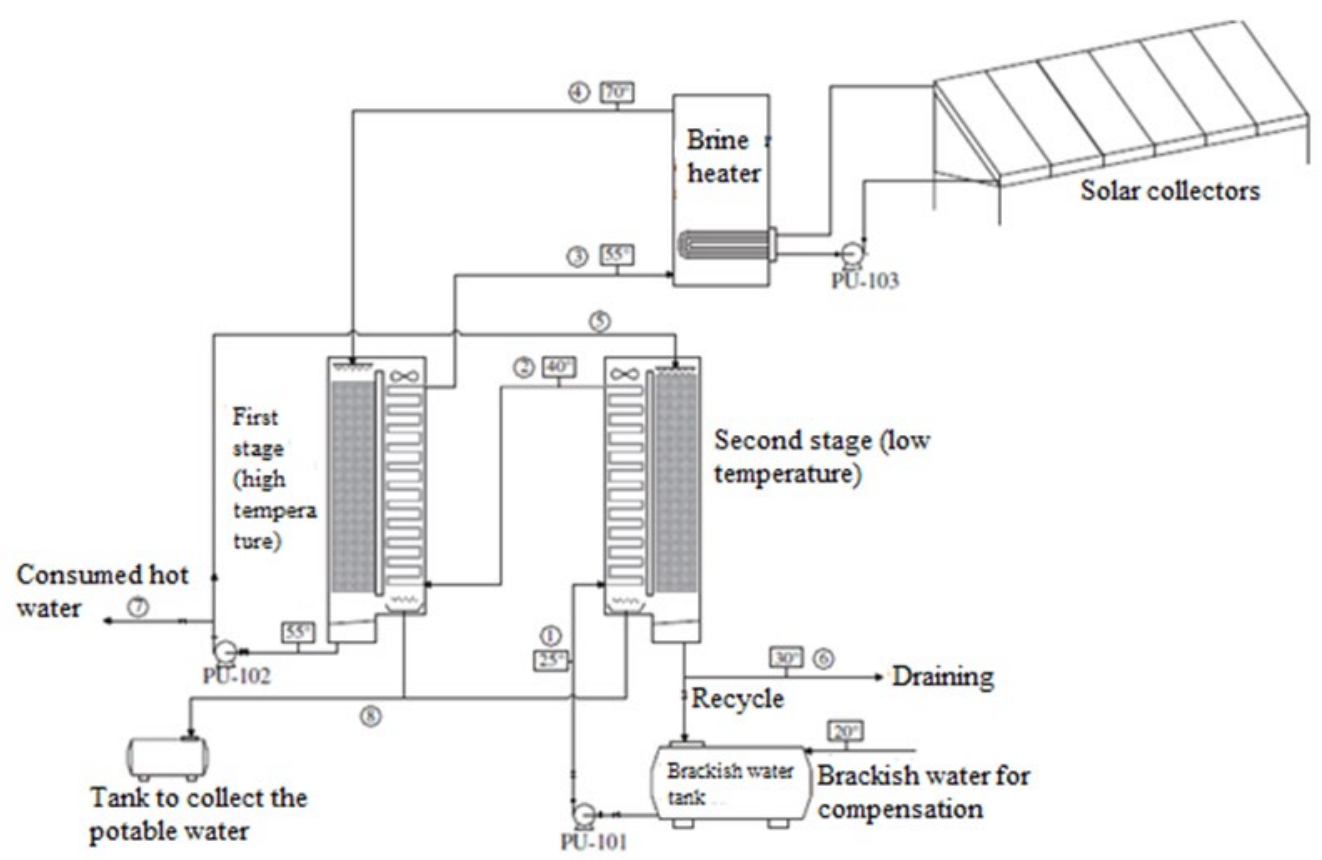

Figure 8: Disposition of the two-stage desalination plant. Adapted from ref. [36].

Juarez-Trujillo et al. [30] accomplished at TRNSYS software, the simulation and parametric analysis of an HDH desalination system provided by solar energy. In the simulation, it was projected equipment aiming to achieve the maximum individual efficiency. Thus, it was performed by heating and recirculation of the water and air currents. The heating was performed with oil at the temperature of $110^{\circ} \mathrm{C}$ as the evaporative process occurred at a higher temperature without boiling the water, maximizing the vapor quantity transported by the air current. The simulated process needed a capture and thermal oil storage system, being an isolated tank and an evacuated pipe connected to the solar collectors, enabling the operations of the system at night. The condenser was projected with an area excess for the air returned to the ambient temperature, and a larger quantity of water was condensed. A controlled flux system was used, enabling to set the obtained temperature by the water that flows for an evaporation tower, aiming to keep it at $90^{\circ} \mathrm{C}$ during the daily operation. A parametric study was accomplished, where it was determined the effects of variation in the collector's numbers, the thermal tank volume, and the water flow rate. The used climate conditions were equal to the Chihuahua city, Mexico, simulating the system behavior throughout a year of continuous operation, measuring the condensed quantity produced during this time. In this paper, it was calculated the production variation in kilograms of distilled water by year by the solar collect square meter and by thermal tank cubic meter.

Zubair [6] analyzed the HDH system integrated to collectors' tubes for the water heating, which is searched to avail the solar energy for this type of system. Besides, it has explored the possibility of coupling with the thermal storage tank, variating the input fluxes. The study also involved the variation of the system location, proposing an optimal configuration that might variate from city to city, according to the climate conditions of each one. It is noticed that a high flux in the storage tank leads to great productivity, although for a small period of hours. For a low flux, there is small productivity; however, there is a high number of operating hours. Therefore, it was achieved the optimal flux so the system could be able to operate 24 hours, being self-sufficient. The paper concluded that the systems with coupled storage tanks are more productive than the direct HDH's. The expected durability for the plant was 20 years, where the operation cost per freshwater liter variates between $\$ 0.018$ and $\$ 0.024$.

Enayatollahi [37], at his thesis, investigated the heat and mass transference at the humidification and dehumidification phenomenon in open-air/open-water system, noticing that this would be the relevant parameter 
to measure the collected potable water quantity. Therefore, it was proposed a system where the water passed by the cascade in the humidifier, aiming to improve the transference rates. It was found dimensionless parameters for the model, enabling the influence analyses of the diverse existent variables in the new system. Among the studied conditions, it was noted that the saline water evaporation before its entrance in the humidifier leads to a production fall, due to the difficulty in the condensation stage. Therefore, when the air flux enters in overheating conditions, this must suffer cooling until its dew point. Consequently, an additional condensation area might be necessary, due to the increase of the flux's temperature is not always attractive. For a given seawater input temperature, the flux increase of this fluid decreases the potable water production. This finding is due to the flux does not receive enough energy in the collector to evaporate in the humidifier. The implementation of the cascade process represented an increase of $15 \%$ at the system income, where the required was reduced for one-quarter of the needed over the humidifier channel. Also, this thesis studies the solar heating coupling to the desalination system, something usually applied in the other studies.

Ahmed et al. [38] accomplished an experimental study in which they analyzed the performance of an HDH desalination system. The main analyzed variables were the air and water temperatures that enter the humidifier, the water, and the air mass rate, besides the cooling water mass flux that enters the condenser. The news of this paper is the use of a layer in the humidifier formed by corrugated aluminum sheets, and this device has the purpose of increasing the air contact surface with the water. Consequently, there are improvements in the heat and mass transference processes. The proposed model presented a small pressure fall than the sprinkler nozzles, which are typically used. Besides, this layer presented facilities as cleaning and maintenance. One of the more significant findings obtained was the big influence of the air and cooling water mass fluxes in the condenser efficiency. For the created unity, the maximum productivity achieved was $15 \mathrm{~kg} \cdot \mathrm{h}^{-1}$. Furthermore, it was performed a cost analysis that analyzed a plant for ten years.

Elsafi [39] developed a theoretical study on Engineering Equation Solver (EES) software to analyze the performance of a cogeneration unity based on the integration of an HDH desalination cycle with a concentrated photovoltaic-thermal collector (CPVT). This study aimed the potable water production as the electric energy, and accomplished the cost and quantities produced estimated for each utility per year. In this study, there is only the air current heating, which decreases the cost with solar collectors due to the equipment simplicity, although there is a system efficiency fall concomitantly.

Correlations to stimulate the saline water properties according to the temperature, salinity, and pressure variation were aborted at Nayar et al. study. [40] This paper was based on Elsafi [39] to find the thermophysical properties of the saline water needed to project a desalination plant. The negligence of the variations caused in the saline water properties by the presence of salts led to mistakes up to $20 \%$ in the obtained results. [41] The meteorological conditions used were the same as Dhahran city, Saudi Arabia.

Rajaseenivasan and Srithar [42] performed an experimental study to evaluate the efficiency of an HDH system with the packing layer. The heating in this system is a dual-purpose solar collector, where the water and air currents are heated simultaneously. Semicircular tabulators are added to the air flux in the solar collector, aiming to increase the temperature of the fluid before it enters the humidifier. The authors evaluated the system performance through a hot air and water flux variation that enters the humidifier, besides the cooling water flux in the condenser.

Mahdizade and Ameri [43] accomplished a theoretical study with Engineering Equation Solver (EES) software due to the modeling of a semi-open-air/open water HDH desalination system. In this study, it was heated the air and water current, the supply proportion of energy variated between both currents aiming to find a higher rate. According to the performed analysis, the authors noticed that the HDH system is efficient at dry climates, as well as the humid ones. In the semi-open-air/open water system, part of the air that leaves the condenser mix with the ambient air, uniting in a single flux that will supply the humidifier. The analysis of the unity efficiency variation with the contribution of each current was accomplished. It was found that for 40 and $45^{\circ} \mathrm{C}$ temperatures, the system GOR increased as the unity approximate to an air closed flux. Temperatures over to $55^{\circ} \mathrm{C}$, the behavior is raised until an optimal point, where there is a decrease in the income. The analysis of the ambient temperature variation has shown that this parameter has a significant impact on system performance than the relative humidity. It is noticed that in overheated air and water cycles under high ambient temperature, the close cycle presented better performance. However, the open cycle is more efficient for small ambient temperatures. The semi-open-air/open water cycle only showed itself interesting for temperatures between 15 and $30^{\circ} \mathrm{C}$; at icy locations, the adoption of the open-air cycle is an unanimity. Analogously, at tropical locations, the adoption of a closed air cycle is unquestionable. 
Matheus Dias de Carvalho, Jane Selia dos Reis Coimbra, Tiago Silva Miranda Lemos, Jorge David Alguiar Bellido, and Antônio Marcos de Oliveira Siqueira

Campos et al. [44] performed a theoretical study using the MATLAB software proposing a mathematical model to predict and to optimize the produced distilled quantity by an HDH desalination system. The proposed model is compared to the other seven methodologies, presenting to be more efficient than this. A multi objective global function achieved the parametric analysis, among the found data, there are the optimum condenser and humidifier heights. Also, it was evaluated the importance of considering the presence of sodium chloride in the solution, besides to work with a humidifier output current with non-saturated air.

Yang [45] performed a theoretical study to evaluate the performance of an HDH desalination system from the variation of the system pressure or only the humidification chamber. A vacuum pump to conduce the air circulation was used to create pressures of until $0.2 \mathrm{~atm}$, being this the only device supplied by electrical energy. Another critical point of this study is the analysis of a plant built under the sea; something still little explored in the literature. The great advantage of this type of approach is the possibility to use four types of renewable energy sources, being these solar, wind, wave power, and tidal power.

Li et al. [46] studied an HDH desalination system heated by solar energy and with a humidification system formed by a porous membrane through the modeling by Fortran code to assess the effects of the membrane characteristics in unity performance. It is a theoretical and experimental study, where it evaluates three types of membranes with different mass diffusivities, surface areas, and thermal conductivities. Of the analyzed coefficients, the mass diffusivity and the total surface are the most relevant parameters for the potable water production. The use of porous membranes is justified by the small specific surface area in the used layers of other HDH plants, not overcoming $100 \mathrm{~m}^{2} \cdot \mathrm{m}^{-3}$, while the porous membranes of this study achieve $809 \mathrm{~m}^{2} \cdot \mathrm{m}^{-3}$.

Huang et al. [47] accomplished a theoretical study to evaluate the thermodynamic models, and the pressure falls where they could predict and optimize the performance of an HDH desalination system. The results of the simulation are obtained from the MATLAB and Aspen Plus software, which are compared with experimental data presented in the literature. The optimization is performed through the variation of the saline water mass flux and the input humidifier temperature, presented to be the main parameters to influence the efficiency. An analysis of the electric energy consumed was made, which has shown negligible according to the total supplied energy.

It is aiming to approach with greater depth the presented studies; Table 2 and Table 3 additional exhibit information to clarify the project details, configurations, and main conclusions. The experimental studies limit Table 2 , while Table 3 includes modelling and theoretical papers. Therefore, this article differs from the current approach of state of the art, presenting various modifications and obtained results by the studies of HDH desalination systems. Among the alterations, it is cited the fluids circulation form, the membrane's presence, the geometries, the layers composition, and the presence of a thermal storage tank.

Table 2: Representation of the main information presented in the experimental studies of HDH desalination. Part A

\begin{tabular}{|c|c|}
\hline System type, location, operation and project data & Main observations \\
\hline \multicolumn{2}{|l|}{ Al-Hallaj, Farid, and Tamimi (1998) - ref [12] } \\
\hline $\begin{array}{l}\text { - Closed air/open water. } \\
\text {-Humidifier with a wood layer with } 87 \mathrm{~m}^{2} \cdot \mathrm{m}^{-3} \text { for } \\
\text { the pilot plant and } 14 \mathrm{~m}^{2} \cdot \mathrm{m}^{-3} \text { for bench scale. } \\
\text {-Water temperature that enters the humidifier } \\
\text { variated between } 60 \text { and } 63 \text { o C. } \\
\text {-Condenser area of } 0.6 \mathrm{~m}^{2} \text { for bench scale and } \\
8.0 \mathrm{~m}^{2} \text { for the pilot plant. } \\
\text { - Flat solar collector and electric resistance of } 2.5 \\
\mathrm{~kW} \text {. }\end{array}$ & $\begin{array}{l}\text {-An increase in the water flux raises the mass transference } \\
\text { rate due to a higher quantity of available fluid. } \\
\text {-An increase in the water flux decreases the water } \\
\text { temperature that enters the humidifier. } \\
\text {-Air velocity is only a significant parameter of temperatures } \\
\text { lower than } 50^{\circ} \text { C. }\end{array}$ \\
\hline \multicolumn{2}{|l|}{ Nawayseh, Farid, Al-Hallaj et al. (1999) - ref [26] } \\
\hline $\begin{array}{l}\text { - Closed air/open water. } \\
\text {-Natural convection for the air. } \\
\text {-Humidifier with wooden packing layer and } \\
\text { surface area of } 5.04 \mathrm{~m}^{2} \text {. } \\
\text {-Ratio variation between the saline water and air } \\
\text { input rate of } 1 \text { to } 10 \text {. }\end{array}$ & $\begin{array}{l}\text { - Mass transference coefficients in the humidifier present } \\
\text { stronger dependency in the water flux. } \\
\text { - There was no significant improvement in the use of air flux } \\
\text { for forced convection. } \\
\text { - The bigger the water flux, the bigger must be the air flux. }\end{array}$ \\
\hline
\end{tabular}




\begin{tabular}{|c|c|}
\hline $\begin{array}{l}\text { - Water flux variation between } 7.20 \text { and } 144.00 \\
\mathrm{~kg} \cdot \mathrm{h}^{-1} \text {. } \\
\text { - The optimum productivity reached was } 1.70 \\
\mathrm{~kg} \cdot \mathrm{h}^{-1} \text { for the power of } 1 \mathrm{~kW} \text {. } \\
\text { - Electric heating and flat plates solar collector. }\end{array}$ & $\begin{array}{l}\text { - Air fluxes too big produce excessive heat losses in the } \\
\text { condenser and the humidifier. } \\
\text { - The higher the contact area in the humidifier and the } \\
\text { condenser, the bigger will be the productivity. }\end{array}$ \\
\hline \multicolumn{2}{|l|}{ Dai and Zhang (2000) - ref [10] } \\
\hline $\begin{array}{l}\text { - Open-air/closed water. } \\
\text {-Air flows through a straight channel, avoiding } \\
\text { pressure losses. } \\
\text {-The maximum thermal efficiency of } 85 \% \text {. } \\
\text { - An average productivity of } 26 \mathrm{~kg} \cdot \mathrm{m}^{-2} \cdot \mathrm{h}^{-1} \text {. } \\
\text {-Solar collector under average radiation of } 700 \\
\mathrm{~W} \cdot \mathrm{m}^{-2} \text {. }\end{array}$ & $\begin{array}{l}\text {-The system efficiency increases with the input water } \\
\text { temperature in the humidifier, beyond the water and air } \\
\text { mass flux. } \\
\text {-The lower the input water temperature in the humidifier, } \\
\text { the bigger will be the optimal rotation for the compressor. }\end{array}$ \\
\hline
\end{tabular}

Table 2: Part B

\begin{tabular}{|l|}
\hline System type, location, operation and project data \\
\hline Zamen et al. (2014) - ref [36] \\
\hline -Closed air/closed water. \\
- The pilot plant built in an arid region in a central \\
local of Iran. \\
-Two stages. \\
-Use of storage tank. \\
-Air flows by forced circulation. \\
-Use of packing layer based on polypropylene, \\
with a specific surface area of $240 \mathrm{~m}^{2} \cdot \mathrm{m}^{-3}$. \\
-Condensers with $30 \mathrm{~m}^{2}$ of the $\mathrm{area}^{-}$of thermic \\
exchange. \\
- Saline water mass flux of until $1400 \mathrm{~kg} \cdot \mathrm{h}^{-1} \cdot$ \\
-Cooling water temperature equal to $20^{\circ} \mathrm{C}$, while \\
the humidifier input saline water of $70^{\circ} \mathrm{C}$. \\
-Water salinity equal to $4500 \mathrm{ppm}^{-}$ \\
-Daily production of $0.31 \mathrm{~kg} \cdot \mathrm{h}^{-1} \cdot \mathrm{m}^{-2}$. \\
- Solar collector with $80 \mathrm{~m}^{2}$. \\
\hline
\end{tabular}
Main observations

-The two-stage system increases more than $35 \%$ of the energy recovery in the condenser, and consequently, it reduces the thermic energy consumption. This system presented a better option for the costs of produced water quantity, and it is $20 \%$ more efficient than the one-stage system.

-Systems with more than two stages do not present significant improvement.

-The increase of the daily production per solar collector unity was superior to $40 \%$ for two stages.

-The ratio between the saline water and the air flux decreases with the humidifier input water temperature fall.

-The bigger the saline water flux, the higher the productivity. -More than $75 \%$ of water production occurs in the first stage.

Ahmed et al. (2017) - ref [38]

-Open-air/closed water.

-The plant developed in Egypt.

-Use of packing layer in the humidifier, formed by aluminum corrugated sheets.

-The condenser is a compact heat exchanger with a surface area of $13 \mathrm{~m}^{2}$.

-Use of storage tank for the saline water.

-Air velocity variated between 0.8 and $15 \mathrm{~m} \cdot \mathrm{s}^{-1}$.

-Operation under atmospheric pressure.

-It was considered an adiabatic system in the energy balance; in the summer, it was a reasonable approximation due to the low difference between the system and ambient temperatures. Besides the well isolated humid.

-Use of cooling water.

-Maximum productivity of $15 \mathrm{~kg} \cdot \mathrm{h}^{-1}$.

Rajaseenivasan and Srithar (2017) - ref [42] 
-Open-air/closed water.

-Experiments performed between October of 2015 and February of 2016. Installation in the Madurai city, India.

-Packing layer with a surface area of $0.09 \mathrm{~m}^{2}$.

-Use of cooling water.

-The turbulence created by obstacles in the air flux of the solar collector, increasing the air temperature before it enters the humidifier.

-Air flux variation between 50.4 and $64.8 \mathrm{~kg} \cdot \mathrm{h}^{-1}$.

-Saline water flux variation between 60 to 180 $\mathrm{kg} \cdot \mathrm{h}^{-1}$.

-Cooling water flux variation between 90 and 210 $\mathrm{kg} \cdot \mathrm{h}^{-1}$.

-The average efficiency of $67.6 \%$.

-Maximum productivity of $0.63 \mathrm{~kg} \cdot \mathrm{m}^{-2} \cdot \mathrm{h}^{-1}$, using concave turbulators.

-Dual-purpose solar collector, heating the air, and the water current.
-Increase of the productive capacity with the raise of the air and water flux temperature that enters the humidifier.

-Increase of productivity with the air, saline water, and cooling water flux raise.

-Concave turbulators presented efficiency 23\% bigger than the conventional system and $7.7 \%$ superior to the convex turbulators.

-A decrease in the production cost with the air flux increase. The minimum cost of $\$ 0.0257$ per produced potable water liter by the concave turbulators system.

Table 3: Representation of the main information presented in the modelling and theoretical studies of HDH desalination. Part A

\begin{tabular}{|c|c|}
\hline $\begin{array}{l}\text { System type, location, operation and project } \\
\text { data }\end{array}$ & Main observations \\
\hline \multicolumn{2}{|l|}{ Nawayseh et al. (1997) - ref [25] } \\
\hline $\begin{array}{l}\text {-Closed air/open water. } \\
\text {-Closed air/open water. } \\
\text {-Wooden packing layer with surface area } \\
\text { variating between } 2 \text { to } 23 \mathrm{~m}^{2} \text {. Optimal area } \\
\text { of } 5.6 \mathrm{~m}^{2} \text {. } \\
\text {-Condenser area variation between } 1 \text { to } 40 \\
\mathrm{~m}^{2} \text {. Optimal area of } 4 \mathrm{~m}^{2} \text {. } \\
\text {-Water flux variation between } 18 \text { to } 43.2 \\
\mathrm{~kg} \cdot \mathrm{h}-1 \text {. An optimal flux of } 25.2 \mathrm{~kg} \cdot \mathrm{h}^{-1} \text {. } \\
\text {-Air flux variation between } 18 \text { to } 54 \mathrm{~kg} \cdot \mathrm{h}^{-1} \text {. } \\
\text { An optimal flux of } 21.6 \mathrm{~kg} \cdot \mathrm{h}^{-1} \text {. } \\
\text {-Optimal productivity of } 0.48 \mathrm{~kg} \cdot \mathrm{h}^{-1} \cdot \mathrm{m}^{-2} \text {. } \\
\text {-Electric pre-heating of } 2.5 \mathrm{~kW} \text { and flat plate } \\
\text { solar collector of } 2 \mathrm{~m}^{2} \text {. }\end{array}$ & $\begin{array}{l}\text {-Significant increase in the mass and heat transference coefficients } \\
\text { with the water flux raise. } \\
\text {-Water flux increase decreases the humidifier input water } \\
\text { temperature. } \\
\text {-The air flux velocity has small representability; therefore, the } \\
\text { natural convection is a better option. }\end{array}$ \\
\hline \multicolumn{2}{|l|}{ Dai, Wang, and Zhang (2002) - ref [24] } \\
\hline $\begin{array}{l}\text {-Open-air/closed water. } \\
\text {-Forced air flux. } \\
\text {-Use of packing layer in the humidifier. } \\
\text {-Use of cooling water from the sea. } \\
\text {-Water salinity of } 5 \% \text {. } \\
\text {-In the humidifier, it adopted the turbulent } \\
\text { air flux and the laminar water flux. } \\
\text {-Condenser with concentric tubes in } \\
\text { counterflow. } \\
\text {-Maximum productivity of } 0.25 \mathrm{~kg} \cdot \mathrm{m}^{-2} \cdot \mathrm{h}^{-1} \text { of } \\
\text { potable water, for daily supply of } 20 \mathrm{MJ} \text { of } \\
\text { power. }\end{array}$ & $\begin{array}{l}\text {-The potable water quantity produced increases with the raise of } \\
\text { the air temperature, the relative humidity, the seawater, and the } \\
\text { cooling water flux. } \\
\text {-The bigger the air flux, the smaller the productivity. } \\
\text {-The higher the temperature and the relative humidity, the greater } \\
\text { the productivity. } \\
\text {-The lower the cooling water temperature, the higher the } \\
\text { productivity. } \\
\text {-The heat capacity and the water-specific mass increase with the } \\
\text { salt concentration. Consequently, the evaporation rate decreases. } \\
\text { The system is efficient until } 20 \% \text { of salt concentration. }\end{array}$ \\
\hline
\end{tabular}




\begin{tabular}{|c|c|}
\hline $\begin{array}{l}\text {-The solar collector of evacuated tubes. } \\
\text { Average solar radiation of } 700 \mathrm{~W} \cdot \mathrm{m}^{-2} \text {. }\end{array}$ & \\
\hline Yuan and Zhang (2007) - ref [33] & \\
\hline $\begin{array}{l}\text {-Closed air/closed water. } \\
\text {-The plant installed at Xi'an, China. } \\
\text {-Humidifier sprinkles the saline water } \\
\text { through nozzles, and there is not a packing } \\
\text { layer. } \\
\text {-Presence of a saline water storage tank. } \\
\text {-Seawater flux of } 200 \mathrm{~kg} \cdot \mathrm{h}^{-1} \text {. } \\
\text {-Cooling water flux of } 200 \mathrm{~kg} \cdot \mathrm{h}-1 \text {. } \\
\text {-It is used two humidifiers and two } \\
\text { condensers. } \\
\text {-Maximum production of } 2.17 \mathrm{~kg} \cdot \mathrm{h}^{-1} \text { of } \\
\text { freshwater in July. Minimum production of } \\
1.13 \mathrm{~kg} \cdot \mathrm{h}^{-1} \text { of freshwater in December. } \\
\text {-Flat plate solar collector with an area of } 10 \\
\mathrm{~m}^{2} \text {. Solar radiation of } 800 \mathrm{~W} \cdot \mathrm{m}^{-2} \text {. }\end{array}$ & $\begin{array}{l}\text {-The increase of the seawater flux decreases the operation } \\
\text { temperature and productivity but increases the efficiency of the } \\
\text { collector, the humidifier, and the condenser. } \\
\text {-The mass and heat transference coefficients decrease with } \\
\text { temperature. } \\
\text {-The influence in the humidifier length increases with the collector } \\
\text { area rising. } \\
\text {-There is an optimum value for the cooling water flux that } \\
\text { increases with the surface area. The larger the collector area, the } \\
\text { more significant the cooling water flux effect is. } \\
\text {-Decrease of } 5 \% \text { in the production during the night. }\end{array}$ \\
\hline
\end{tabular}

Table 3: Part B

\begin{tabular}{|c|c|}
\hline $\begin{array}{l}\text { System type, location, operation and } \\
\text { project data }\end{array}$ & Main observations \\
\hline \multicolumn{2}{|l|}{ Amer et al. (2009) - ref [34] } \\
\hline $\begin{array}{l}\text {-Closed air/open water. } \\
\text {-The optimal system was operated in } \\
\text { forced convection for the air. } \\
\text {-The coupled wooden layer was the } \\
\text { best option for packing material. } \\
\text {-Water enters the humidifier at } 85^{\circ} \mathrm{C} \text {. } \\
\text {-Seawater flux equals to } 168 \mathrm{~kg} \cdot \mathrm{h}^{-1} \text {. } \\
\text {-Seawater flux variation between } 72 \text { to } \\
180 \mathrm{~kg} \cdot \mathrm{h}^{-1} \text {. } \\
\text {-Humidifier input water temperature } \\
\text { variation between } 50 \text { to } 85^{\circ} \mathrm{C} \text {. } \\
\text {-Condenser output water temperature } \\
\text { variation between } 30 \text { to } 45^{\circ} \mathrm{C} \text {. } \\
\text {-Humidifier and condenser surface } \\
\text { areas equal to } 6 \mathrm{~m}^{2} \text {. } \\
\text {-Maximum productivity of } 5.8 \mathrm{~kg} \cdot \mathrm{h}^{-1} \text {. } \\
\text {-Solar collector. }\end{array}$ & $\begin{array}{l}\text {-It occurs a productivity increase with the seawater flux, condenser } \\
\text { input and output humidity raise. } \\
\text {-It was verified the proportionality between the humidifier input water } \\
\text { temperature and the condenser output water temperature. } \\
\text {-The humidifier input water temperature decreases with the process } \\
\text { input saline water mass flux increase. } \\
\text {-The bigger the humidifier input water temperature, the greater will be } \\
\text { the condenser input and output air temperatures and humidity. } \\
\text {-Air forced convection did not present significant improvements for the } \\
\text { air at high temperatures. }\end{array}$ \\
\hline \multicolumn{2}{|c|}{ Mahmoud, Farrag, and Mohamed (2013) - ref [35] } \\
\hline $\begin{array}{l}\text {-Comparative study between closed } \\
\text { air/ closed water and open-air/closed } \\
\text { water systems. } \\
\text {-Installation at Mynia Governorate, } \\
\text { Egypt. } \\
\text {-Only one stage. } \\
\text {-Average air flux equals } 510 \mathrm{~kg} \cdot \mathrm{h}^{-1} \text { and } \\
\text { an average velocity of } 4.5 \mathrm{~m} \cdot \mathrm{s}^{-1} \text {. } \\
\text {-Relative humidity between } 30 \text { to } 40 \% \text {. } \\
\text {-The thermal storage tank of glass wool } \\
\text { coated steel. }\end{array}$ & $\begin{array}{l}\text {-The better results were obtained for the closed air cycle. } \\
\text {-The Fresnel lenses presented efficiency of until 70\% for clean days. } \\
\text {-It is noticed a small dependency on the water evaporation rate with the } \\
\text { air velocity; therefore, there is a strong dependency on the diameter of } \\
\text { the spayed drop. Thus, the smaller the particle size, the bigger will be } \\
\text { the evaporation rate. } \\
\text {-The higher the humidifier input water temperature, the greater the } \\
\text { productivity. }\end{array}$ \\
\hline
\end{tabular}


-Humidification and dehumidification of cubic chambers of galvanized steel coated by a polymeric layer.

-Use of rotative sprayer to create small drops.

-The productivity of $2.5 \mathrm{~kg} \cdot \mathrm{h}^{-1} \cdot \mathrm{m}^{-2}$ for open-air system and of $4.67 \mathrm{~kg} \cdot \mathrm{h}^{-1} \cdot \mathrm{m}^{-2}$ for the closed air system.

-Electric heater and solar collector optimized with the use of Fresnel lenses. The solar light intensity of 800 $\mathrm{W} \cdot \mathrm{m}^{-2}$.

Juarez-Trujillo et al. (2014) - ref [30]

-Closed air/closed water.

-Climate conditions of Chihuahua, Mexico.

-The Humidifier is a vertical packing tower.

-The heating of the air and water currents by counterflow concentric pipes heat exchanger with thermic oil.

-Use of isolated tank for thermal storage, enabling the day and night system operation.

-Control of the saline water flux was necessary to maintain the system operating for 24 hours.

-Compact condenser.

-Oil temperature equals to $110^{\circ} \mathrm{C}$.

-Humidifier input water temperature of $90 \stackrel{\circ}{\circ}$.

-Solar collector evacuated tubes for the thermic oil heating.

-The numbers of solar collectors varied among 2, 4, 6, 8, 10, and 12 .

-Thermal storage tank volume variation between 1 to $6 \mathrm{~m}^{3}$.

-The water flux that supplies the humidifier variated between 1 to 220

$\mathrm{kg} \cdot \mathrm{h}^{-1}$.
-The potable water production rises as the number of collectors, and the storage tank volume increase.

-For the numbers of collectors between 2 and 6, the increase of the storage tank volume caused a fall of the potable water production. This fact is due to the necessity of a lot of energy to heat a big tank, which is impracticable for a small number of collectors.

-The optimum distilled water production occurs for a storage tank of 6 $\mathrm{m}^{3}$, with the feeding of $70 \mathrm{~kg} \cdot \mathrm{h}^{-1}$ and 12 collectors. This case would have as the results the hourly potable water production of $7.57 \mathrm{~kg}$.

Table 3: Part C

System type, location, operation and project data

Zubair (2015) - ref [6]

-Variation of the location of the system.

-Analysis with or without storage tank, variating the input fluxes.

-System durability expected for 20 years.

-Evacuated tubes solar collector.

Enayatollahi (2016) - ref [37] 
-Open-air/open water.

-Forced circulation for the air and the saline water.

-The humidifier was operating in cascade.

-Input seawater used as a cooling fluid.

-Heating only of the water current.

-Study based on dimensionless parameters.

-Wind velocity of $5 \mathrm{~m} \cdot \mathrm{s}^{-1}$.

-Atmospheric pressure, air temperature of $20^{\circ} \mathrm{C}$, and relative humidity of $50 \%$.

-It is assumed that pure water properties can be applied for seawater.

-Optimal air flux of $91.44 \mathrm{~kg} \cdot \mathrm{h}^{-1}$.

-Shell and tube condenser with one shell pass and two tube passes. Optimal area of $2 \mathrm{~m}^{2}$.

-Humidifier with long channels with air in counterflow with water. Optimal area of $1.4 \mathrm{~m}^{2}$.

-Solar collector, radiation of $1000 \mathrm{~W} \cdot \mathrm{m}^{-2}$.

Elsafi (2017) - ref [39]

-Closed air/open water.

-Dhahran city, Saudi Arabia.

-Analysis under stationary conditions.

-It is neglected the heat loss in the pipes, the ducts, the humidifier, the condenser, and the collector.

-Saline water enters the unity with an average temperature of $22^{\circ} \mathrm{C}$ and a salinity of $35 \mathrm{~g} \cdot \mathrm{kg}^{-1}$.

-Air at $25^{\circ} \mathrm{C}$ and $1 \mathrm{~atm}$.

-The potable water and the saline water leave the system with a salinity of 0 and $35.5 \mathrm{~g} \cdot \mathrm{kg}^{-1}$, respectively.

-Pump and compressor consume 25 and $50 \mathrm{~W}$ of energy, respectively.

-Restrict heating of the air current.

-Use of CPVT system with a double pass for the air. Collector total surface area equals $9 \mathrm{~m}^{2}$.
-Potable water production increases linearly with radiation incidence and ambient air temperature.

-The input seawater raise decreases the production for a given input seawater temperature fixed.

-The turbulent flux in the humidification stage makes the system more efficient due to the increase of the mass transference area, beyond the increase created in the heat and mass transference coefficients.

-Increase of $15 \%$ in the system performance when using the process in cascade. The humidifier required area reduced by $25 \%$.
-Production of $12 \mathrm{~m}^{3}$ of potable water and $960 \mathrm{kWh}$ of electric energy per year for each unity. Result based on the solar incidence of 1.88 MWh per year.

-The daily production of potable water is four times bigger in the summer, while the electric energy is approximately two times bigger. -Cost of $\$ 0.01$ per produced potable water liters, beyond a cost for the electric energy production of $\$ 0.289$ per $\mathrm{kWh}$.

Table 3: Part D

\begin{tabular}{|l|l|}
$\begin{array}{l}\text { System type, location, operation and project } \\
\text { data }\end{array}$ & \multicolumn{1}{|c|}{ Main observations } \\
\hline Mahdizade and Ameri (2018) - ref [43] & $\begin{array}{l}\text {-The bigger the ambient temperature, the major the GOR. } \\
\text {-When the ambient temperature is high, the closed air cycle is } \\
\text { Semi-open air/open water. }\end{array}$ \\
$\begin{array}{l}\text {-Analysis under the stationary state. } \\
\text {-The system operates at atmospheric pressure. } \\
\text {-It is assumed that the condenser and the } \\
\text { humidifier exhaust air are saturated. }\end{array}$ & \\
\hline
\end{tabular}


-Adiabatic humidifier and condenser.

-Ambient air conditions: temperature of $20^{\circ} \mathrm{C}$ and relative humidity of $60 \%$.

-It is assumed that seawater and pure water properties are equal.

-Heating of the air and water currents through a solar collector.

Campos et al. (2018) - ref [44]

Closed air/open water.

-Stationary state model.

-Forced convection for the air.

-Use of packing layer for the humidifier with $112 \mathrm{~m}^{2} \cdot \mathrm{m}^{-3}$ of specific surface area. Transversal section of $0.093 \mathrm{~m}^{2}$.

-Saline water and dry air mass flux of 43.20 and

$144.00 \mathrm{~kg} \cdot \mathrm{h}^{-1}$, respectively.

-It does not consider that the hot air current leaves the humidifier saturated.

-Condenser height variation between 0.25 to $0.70 \mathrm{~m}$.

-Humidifier height variation between 0.25 to $0.60 \mathrm{~m}$.

-Solar incidence variation between 400 and $1300 \mathrm{~W}$.

-Production of $0.051 \mathrm{~kg} \cdot \mathrm{h}^{-1}$ of distillate.

-Solar collector.

-Warming only the water current.

Yang (2019) - ref [45]

-Closed air/open water.

-Use of vacuum pump supplied by electric power.

-Adiabatic humidifier submerged with disc form.

-Air leaves the humidifier, and the condenser saturated.

-There are not expenses with pumping, pretreatments, and brine discard.

-Energy sources: solar, electric, wave power, and eolian.

- A significant part of the plant is submerged, favoring the heating of the cold air current and the cooling of the hot air.

-Air velocity of $2.5 \mathrm{~m} \cdot \mathrm{s}^{-1}$.

-Production of 4 to $11 \mathrm{~kg} \cdot \mathrm{h}^{-1}$ of potable water under optimal conditions, variating with the system size and the climate conditions.

-Heating of the air current by solar energy and wave power.

-Heating of the water current by solar energy with $1000 \mathrm{~W} \cdot \mathrm{m}^{-2}$ and $50 \%$ of efficiency.
-The system achieves the maximum performance when the energy detached to warm the air is close to the quantity used to warm the water.

-For the heating of a unique current, the water heating is more efficient when the supplied energy is low. Otherwise, air heating is the best solution.

-The use of correlations that consider the presence of sodium chloride did not have an impact on system performance.

-An error of $4.3 \%$ in the provision of the produced distillate quantity. The magnitude of $31 \%$ minor than the literature previews.

-The rise of the humidifier height increases the heat transference ratio for the seawater, the heat loss for the ambient, and the air current absolute humidity at the departure of this equipment.

-Condenser and humidifier optimums heights of 0.50 and 0.35 $\mathrm{m}$, respectively.
-The applications of pressure gradients between the humidifier and the condensation stages create excessively high costs with electric energy.

-The optimum operating pressure is near the atmospheric pressure because the gain production created by the pressure fall does not supplement the energetic cost.

-Mixture ratio in the saturation increases with the pressure decrease for a given temperature.

-Great potential for potable water production at large scale and low cost.

-The electrical energy consumed by the vacuum pump of 0.9 to

$1.6 \mathrm{kWh}$ per cubic meter of produced water. 
Table 3: Part E

\begin{tabular}{|c|c|}
\hline System type, location, operation and project data & Main observations \\
\hline \multicolumn{2}{|l|}{ Li, Qi, and Zhang (2019) - ref [46] } \\
\hline 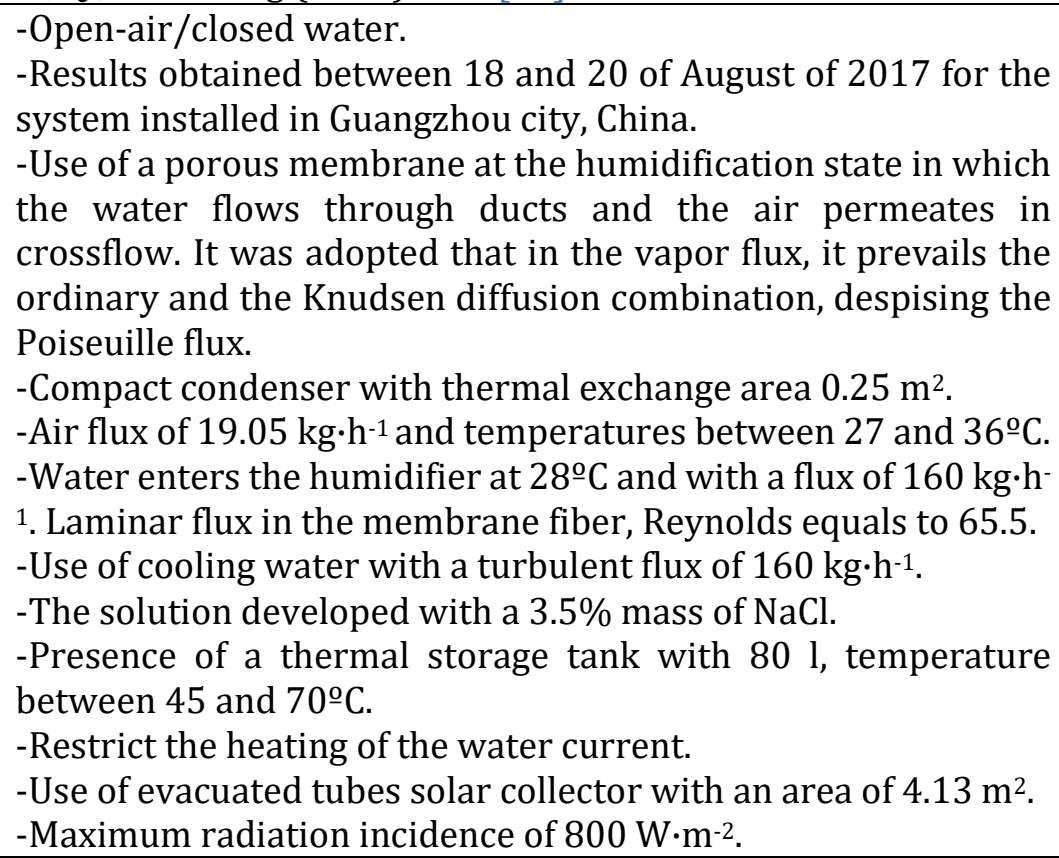 & $\begin{array}{l}\text {-Membranes with high diffusivity capacity and } \\
\text { small thickness are more efficient in the } \\
\text { potable water production. } \\
\text {-It was recorded the presence of a critic } \\
\text { diffusivity valor equals to } 3.0 \cdot 10^{-6} \mathrm{~m}^{2} \cdot \mathrm{s}^{-1} \text {, } \\
\text { though there is no improvement in the system } \\
\text { performance. } \\
\text {-The membrane system has shown superior to } \\
\text { the packing layer. Presenting GOR higher than } \\
\text { the literature for several reasons for air-water } \\
\text { mass flow rate. } \\
\text {-The air velocity presented to be proportional } \\
\text { to the water production until the valor of } 1.1 \\
\mathrm{~m} \cdot \mathrm{s}^{-1} \text {, which there is an asymptote that limits } \\
\text { the production increase. }\end{array}$ \\
\hline \multicolumn{2}{|l|}{ Huang et al. (2020) - ref [47] } \\
\hline $\begin{array}{l}\text { Open-air/closed water. } \\
\text {-Use of dust and impurities collector filter for the air current. } \\
\text {-Use of packing layer with finned sheet metals. The specific } \\
\text { surface area of } 500 \mathrm{~m}^{2} \cdot \mathrm{m}^{-3} \text {. } \\
\text {-The condenser is a compact heat exchanger of stainless steel } \\
\text { with an area of } 27.43 \mathrm{~m}^{2} \text {. } \\
\text {-Minimum consumption of } 220 \mathrm{~kJ} \text { of energy per kilogram of } \\
\text { produced potable water, for air and water mass fluxes of } 400 \\
\text { and } 2230.7 \mathrm{~kg} \cdot \mathrm{h}^{-1} \text {, respectively. } \\
\text {-Restrict the heating of the water current through electric } \\
\text { energy. }\end{array}$ & $\begin{array}{l}\text {-The pressure falls in the system increases } \\
\text { with the air and saline water flux, and with the } \\
\text { humidifier input water temperature. } \\
\text { Deviations minors than } 15 \% \text { with } \\
\text { experimental data. } \\
\text {-The consumed electric energy represented } \\
\text { 9.9\% of the totality. } \\
\text {-The optimal temperature for the humidifier } \\
\text { input saline water is equal to } 76.4 \stackrel{\circ}{\circ} \text {. }\end{array}$ \\
\hline
\end{tabular}

\section{CONCLUSIONS}

The present paper aimed to present the state of art of an HDH desalination system. From the analysis of the most recent articles, it is noted the predominance of the closed air/open water configuration due to the energetic utilization of the air current, besides, dismiss additional current of thermal exchange in the condenser and avoid the salts accumulation in the system. The accumulation is associated with incrustation, corrosion, and damages at the equipment structures.

Renewable energetics matrixes are fundamentals for the desalination systems to achieve economic viability, being the solar energy unanimity in the fluid current heating, in general, the saline water current. The desalination plants installation under the sea is another news that the studies presented, a choice that facilitates the use of wave power and tidal power. The use of packing layers and membranes have been used as an unquestionable form to increase the mass transference in the humidification stage; recent studies aim to find geometries and materials that optimize this stage. For the condensation stage, the use of compact condenser become ideal for working with thermal exchanges evolving gas fluids. Considerations of the water chemical composition in some theoretical studies still are unknown, existing disagreements in the conclusions, a question that still must be worked in future simulations. The vast majority of studies utilize the Engineering Equation Solver (EES) software for HDH plant modeling, which is an 
Matheus Dias de Carvalho, Jane Selia dos Reis Coimbra, Tiago Silva Miranda Lemos, Jorge David Alguiar Bellido, and Antônio Marcos de Oliveira Siqueira

excellent alternative to resolve several equations simultaneously. Finally, this article hopes to contribute to the understanding of HDH desalination systems, being an update of the advances presented in the literature.

\section{SOURCES OF FUNDING}

None.

\section{CONFLICT OF INTEREST}

None.

\section{ACKNOWLEDGMENT}

The authors would like to acknowledge the Universidade Federal de Viçosa (UFV). This study was accomplished with the support of the Coordenação de Aperfeiçoamento de Pessoal de Nível Superior - Brazil (CAPES) - Código de Financiamento 001 and the Fundação de Amparo à Pesquisa do Estado de Minas Gerais (FAPEMIG).

\section{REFERENCES}

[1] United Nations Children Fund, World Health Organization, Progress on Drinking Water, Sanitation and Hygiene, 2017, 66, doi:10.1111/tmi.12329.

[2] M. M. Mekonnen, A. Y. Hoekstra, Four Billion People Facing Severe Water Scarcity, Science Advances, 2016, 2, 1.

[3] H. T. El-Dessouky, H. M. Ettouney, Fundamentals of Salt Water Desalination, Amsterdam. Elsevier., 2002.

[4] J. Eliasson, The Rising Pressure of Global Warming Shortages, Nature, 2015, 517, 6.

[5] K. C. Ng, K. Thu, S. J. Oh, L. Ang, M. W. Shahzad, A. N. Ismail, Recent Developments in Thermally-Driven Seawater Desalination: Energy Efficiency Improvement by Hybridization of the MED and AD Cycles, Desalination, 2015, 356, 255.

[6] M. I. Zubair, Thermal and Economical Analysis of HDH Systems Driven by Solar Thermal Energy with a Storage Option, Dhahran, 2015.

[7] S. Mustafa, R. Shapawi, Aquaculture Ecosystems Adaptability and Sustainability, Pondicherry: John Wiley \& Sons, doi:10.1002/9781118778531. 2015.

[8] G. P. Narayan, M. H. Sharqawy, E. K. Summers, J. H. Lienhard, S. M. Zubair, M. A. Antar, The Potential of SolarDriven Humidification-Dehumidification Desalination for Small-Scale Decentralized Water Production, Renew. Sustain. Energy Rev. 2010, 14, 1187.

[9] J. J. Hwang, Promotional Policy for Renewable Energy Development in Taiwan, Renew. Sustain. Energy Rev., 2010, 14, 1079.

[10] Y. J. Dai, H. F. Zhang, Experimental Investigation of a Solar Desalination Unit with Humidification and Dehumidification, Desalination, 2000, 130, 169.

[11] S. W. Sharshir, N. Yang, G. Peng, A. E. Kabeel, Factors Affecting Solar Stills Productivity and Improvement Techniques: A Detailed Review, Appl. Therm. Eng., 2016, 100, 267.

[12] S. Al-Hallaj, M. M. Farid, A. R. Tamimi, Solar Desalination with a Humidification - Dehumidification Cycle: Performance of the Unit, Desalination, 1998, 120, 273.

[13] M. Ben Amara, I. Houcine, A. Guizani, M. Măalej, Experimental Study of a Multiple-Effect Humidification Solar Desalination Technique, Desalination, 2004, 170, 209.

[14] Y. Ho-Ming, T. Lin-Wen, C. Lie-Chaing, Basin-Type Solar Distillers with Operating Pressure Reduced for Improved Performance, Energy, 1985, 10, 683.

[15] M. S. Hassan, S. Toyama, M. A. Wahhab, Multieffect Solar Still for Agricultural Purposes in Hot Climate, 1989, $71,347$.

[16] H. M. Yeh, Z. F. Chen, Energy Balances for Upward-Type, Double-Effect Solar Distillers with Air Flow through the Second-Effect Unit, Energy, 1994, 19, 619. 
[17] M. Darwish, Desalination process: A technical comparison, IDA World Congr. Desalin. Water Sci., 1995, 149, doi:10.1080/02508067608685707.

[18] S. C. Maroo, D. Y. Goswami, Theoretical Analysis of a Single-Stage and Two-Stage Solar Driven Flash Desalination System Based on Passive Vacuum Generation, Desalination, 2009, 249, 635.

[19] H. Strathmann, Ion-Exchange Membrane Separation Process, Stuttgart, Elsevier, 2004.

[20] J. J. Qin, W. C. L. Lay, K. A. Kekre, Recent Developments and Future Challenges of Forward Osmosis for Desalination: A Review, Desalin. Water Treat., 2012, 39, 123.

[21] C. Li, Y. Goswami, E. Stefanakos, Solar Assisted Sea Water Desalination: A Review, Renew. Sustain. Energy Rev., 2013, 19, 136.

[22] G. Amy, N. Ghaffour, Z. Li, L. Francis, R. V. Linares, T. Missimer, S. Lattemann, Membrane-Based Seawater Desalination: Present and Future Prospects, Desalination 2017, 401, 16.

[23] H. Muller-Holst, Solar Thermal Desalination Using the Multiple Effect Humidification (MEH)-Method, Solar. Desalin. 21st Century, 2007, 215, doi: https://doi.org/10.1007/978-1-4020-5508-9_16.

[24] Y. J. Dai, R. Z. Wang, H. F. Zhang, Parametric Analysis to Improve the Performance of a Solar Desalination Unit with HDH, Desalination, 2002, 142, 107.

[25] N. K. Nawayseh, M. M. Farid, A. A. Omar, S. M. Al-Hallaj, A. R. Tamimi, A Simulation Study to Improve the Performance of a Solar Humidification-Dehumidification Desalination Unit Constructed in Jordan, Desalination, 1997, 109, 277.

[26] N. K. Nawayseh, M. M. Farid, S. Al-Hallaj, A. R. Al-Timimi, Solar Desalination Based on Humidification Process - I. Evaluating the Heat and Mass Transfer Coefficients, Energy Convers. Manag., 1999, 40, 1423.

[27] N. K. Nawayseh, M. M. Farid, A. A. Omar, A. Sabirin, Solar Desalination Based on Humidification Process - II. Computer Simulation, Energy Convers. Manag., 1999, 40, 1441.

[28] E. Chafik, A New Type of Seawater Desalination Plants Using Solar Energy, Desalination, 2003, 156, 333.

[29] M. T. Chaibi, A. M. El-Nashar, Solar Thermal Processes, Seawater Desalin., 2009, 131, doi: https://doi.org/10.1007/978-3-642-01150-4.

[30] A. Juarez-Trujillo, I. R. Martín-Domínguez, M. T. Alarcón-Herrera, Using TRNSYS Simulation to Optimize the Design of a Solar Water Distillation System, Energy Procedia, 2014, 57, 2441.

[31] J. A. E. Bretano, Desalinización Solar de Agua Por Humidificación- Dehumidificación de Aire Simulado En Trnsys, Chihuahua:Centro de Investigacion en Materiales Avanzados2010, 81.

[32] M. H. Sharqawy, M. A. Antar, S. M. Zubair, A. M. Elbashir, Optimum Thermal Design of Humidification Dehumidification Desalination Systems, Desalination, 2014, 349, 10.

[33] G. Yuan, H. Zhang, Mathematical Modeling of a Closed Circulation Solar Desalination Unit with HumidificationDehumidification, Desalination 2007, 205, 156.

[34] E. H. Amer, H. Kotb, G. H. Mostafa, A. R. El-Ghalban, Desalination, Theoretical and Experimental Investigation of Humidification-Dehumidification Desalination Unit, 2009, 249, 949.

[35] M. S. Mahmoud, T. E. Farrag, W. A. Mohamed, Experimental and Theoretical Model for Water Desalination by Humidification - Dehumidification (HDH), Procedia Environ. Sci. 2013, 17, 503.

[36] M. Zamen, S. M. Soufari, S. Abbasian Vahdat, M. Amidpour, M. A. Zeinali, H. Izanloo, H. Aghababaie, Experimental Investigation of a Two-Stage Solar Humidification-Dehumidification Desalination Process, Desalination, 2014, 332, 1.

[37] R. Enayatollahi, Development and Analysis of a Solar Humidification Dehumidification Desalination System, 2016.

[38] H. A. Ahmed, I. M. Ismail, W. F. Saleh, M. Ahmed, Experimental investigation of humidificationdehumidification desalination system with corrugated packing in the humidifier, Desalination, 2017, 410, 19.

[39] A. M. Elsafi, Integration of Humidification-Dehumidification Desalination and Concentrated PhotovoltaicThermal Collectors: Energy and Exergy-Costing Analysis, Desalination, 2017, 424, 17.

[40] K. G. Nayar, M. H. Sharqawy, L. D. Banchik, J. H. Lienhard, Thermophysical Properties of Seawater: A Review and New Correlations That Include Pressure Dependence, Desalination, 2016, 390, 1.

[41] M. H. Sharqawy, J. H. L. V, S. M. Zubair, On Exergy Calculations of Seawater with Applications in Desalination Systems, Int. J. Therm. Sci., 2011, 50, 187.

[42] T. Rajaseenivasan, K. Srithar, Potential of a Dual-Purpose Solar Collector on Humidification Dehumidification Desalination System, Desalination, 2017, 404, 35. 
[43] E. Z. Mahdizade, M. Ameri, Thermodynamic Investigation of a Semi-Open Air, Humidification Dehumidification Desalination System Using Air and Water Heaters, Desalination, 2018, 428, 182.

[44] B. L. Campos, A. O. Costa, K. C. S. Figueiredo, E. F. Costa Jr., Performance Comparison of Different Mathematical Models in the Simulation of a Solar Desalination by Humidification-Dehumidification, Desalination, 2018, 437, 184.

[45] Y. Yang, Pressure Effect on an Ocean-Based Humidification-Dehumidification Desalination Process, Desalination, 2019, 468.

[46] G. P. Li, R. Hui Qi, L. Z. Zhang, Performance Study of a Solar-Assisted Hollow-Fiber-Membrane-Based Air Humidification-Dehumidification Desalination System: Effects of Membrane Properties, Chem. Eng. Sci., 2019, 206, 164.

[47] X. Huang, T. Ke, X. Yu, L. Weihong, Y. Li, X. Ling, Pressure Drop Modeling and Performance Optimization of a Humidification-Dehumidification Desalination System, Appl. Energy, 2020, 258, 114065. 